\title{
有機薄膜の構造の電子顕微鏡による評価
}

\author{
芦田道夫 \\ 神戸大学工学部 于657 神戸市灘区六甲台町 \\ (1986年 10 月 9 日 受理)

\section{Characterization of the Structure of Organic Thin Films \\ by Electron Microscopy} \\ Michio ASHIDA \\ Faculty of Engineering, Kobe University \\ Rokkodai, Nada-ku, Kobe-shi 657 \\ (Received October 9, 1986)
}

\begin{abstract}
Thin oriented films of some organic compounds can be prepared by either the vacuum-deposition method or the Langmuir-Blodgett method. The characterization of the structure of thin films is carried out by electron microscopy. The orientation of thin films is determined by several experimental methods: electron diffraction, decoration and high resolution electron microscopy for the vacuum-deposited films, and shadowing and replica methods for L-B films.
\end{abstract}

\section{1. まえがき}

有機薄膜を電子デバイス, 光電変換素子, 記憶素子, センサなどに用いようとする最近の研究は, 新しい機能 性材料の開発として注目を集めている。有機分子は大き く分けてパラフィン, 脂肪酸, 高級アルコールなどの鎖 状分子と, ナフタリン, アントラセン及びフタロシアニ ンなどの平面環状分子に分類される。乙のような異方的 構造をむつ有機分子が集合して膜を形成するので, 膜の 構造や物性は分子の配向に大きく依存している。した がって，有機薄膜作製には分子配向を制御する技術の確 立が必要で, 膜の物性は分子配列之関連して検討されな ければならない。

現在分子配向を制御した有機薄膜の製法としてラン グミュア・ブロジェット (Langmuir-Blodgett, LB) 法 と真空蒸着法とが知られており, 膜の構造を評価する方 法には赤外・ラマン分光法 ${ }^{1}, \mathrm{X}$ 線及び光電子分光法 ${ }^{2}$, 低速電子回折法 ${ }^{3)}$, ペニングイオン化電子分光法 ${ }^{4)}$ など のほか電子顕微鏡が用いられている。こてでは電子顕微 鏡による蒸着薄膜及び LB 膜の構造の評価について述 べる。

\section{2. 真空蒸着膜}

\section{1 電子線回折法}

有機化合物を $10^{-2} \mathrm{~Pa}$ 以上の真空中で加熱し, アルカ リハライドや白雲母などの基板結晶のへき開面に蒸着す る。生成膜は炭素蒸着膜で補強し, 水中で基板結晶から はく離して電子顕微鏡用試料とする。電子顕微鏡では膜 の形態観察之同時に, その像之対応した制限視野回折像 が容易に得られ, 結晶型及び分子配向に関する情報を得 ることができる。また, 高分解能回折像により結晶構造 をさらに精密に求めることができる。

電子線回折像の解析には逆格子の概念を用いるのが有 利である。回折の条件はエワルド反射球が逆格子点を切 るととであり，電子線の波長は短かくエワルド反射球の 半径が大きく, 逆格子点の間隔の数十倍もあるので, 反 射球は平面とみなして逆格子面と交差すると考えてよ い。逆格子の強度分布は逆格子点の一点でなく三次元に ひろがり, 試料の厚さが薄いときは厚さ方向に針状に伸 びている。写真フィルム上に現れる回折斑点は逆格子点 及び逆格子点ののびと反射球との交点を示しているか ら, 回折斑点の指数及び強度から電子線の入射方向, す なわち基板の垂直方向と各結晶面との角度を求めること ができる。 
第 6 号 (1986)

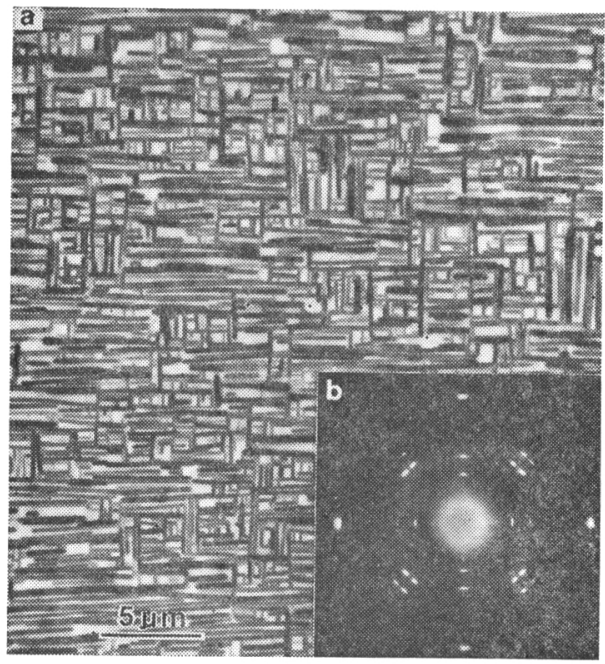

Fig. 1 Electron micrograph (a) and electron diffraction (b) of hexatriacontane film vacuum-deposited on a (001) plane of $\mathrm{KCl}$ crystal which is preheated at $150^{\circ} \mathrm{C}$ and kept at $20^{\circ} \mathrm{C}$.
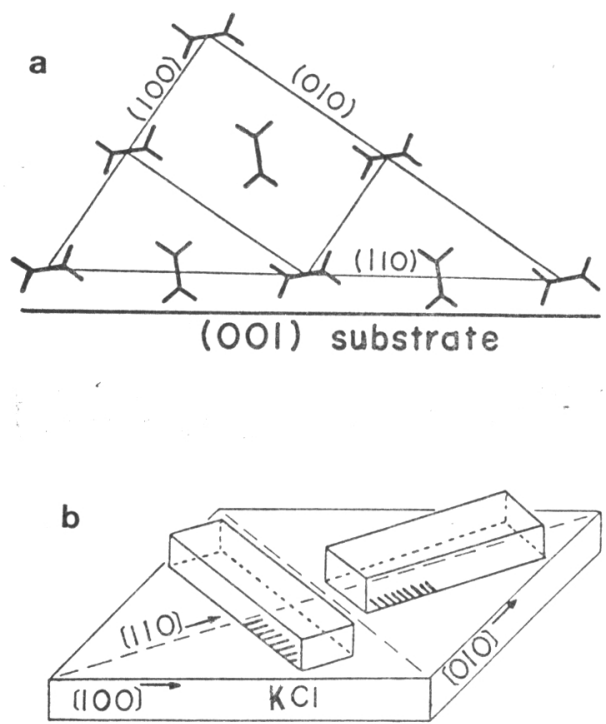

Fig. 2 Schematic diagram of hexatriacontane vacuum-evaporated on a (001) plane of $\mathrm{KCl}$ crystal. (a): The parallel orientation and packing of the chain molecules on the substrate surface, ( b ) : the relative orientation of hexatriacontane crystals and $\mathrm{KCl}(001)$ surface.

Fig. 1 は基板の塩化カリウム結晶のへき開面を真空中 で $150^{\circ} \mathrm{C}$ で熱処理した後室温に保ち, ヘキサトリアコン タン $\left(\mathrm{C}_{36} \mathrm{H}_{74}\right)$ を蒸着した膜とその電子線回折像であ る $^{5)}$ 。膜は直角に交わる2方向に成長した薄い板状晶か ら形成されている。膜が多くの微細結晶から形成されて
いるにもかかわらず，回折像は直角に交わる 2 組の単結 晶眓形に近い回折斑点を与えるととより，微結晶はすへ て同じ配向をとっているととがわかる。回折斑点の面指 数と結晶と基板塩化力リウム結晶との相対的方位上り, ヘキサトリアコンタンの鎖状分子は Fig. 2 のように, 基板結晶の〈110〉方向に沿って平行に吸着し, 最も密に パッキングした（110）面を基板に接し板状に成長して

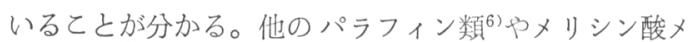
チル77及びポリエチレン ${ }^{8)}$ ，ポリプロピレン などの高分 子の蒸着膜も同様に，鎖状分子が基板に平行で〈110〉方 向に沿って吸着する平行配向をとる。

金属上のヘキサトリアコンタン蒸着膜は分子が基板に 垂直に配列した垂直配向をとる2〉。また，予熱処理なし の岩塩と塩化カリウム結晶上では, ヘキサトリアコンタ ン蒸着膜に平行配向と垂直配向とが混合してくる。塩化 カリウム結晶上に予め $\mathrm{Au}$ を微量蒸着して, Au の微粒 子が一様に分布して局部的に覆っているへき開面上に， ヘキサトリアコンタンを蒸着して膜の配向を調べると, $\mathrm{Au}$ による表面被覆率が増すほど分子の垂直配向をとる 割合が増加し，分子と基板結晶との相互作用が分子配向 に大きく影響を与えているととが分かる10)。ステアリン 酸 $^{11)}$ とステアリン酸カルシウム ${ }^{12)}$ のアルカリ八ライド及 び白雲母基板上の蒸着膜も，分子が垂直または平行に配

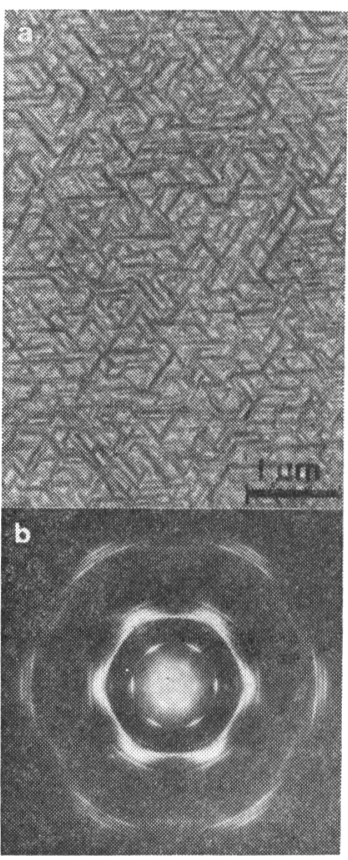

Fig. 3 Electron micrograph (a) and electron diffraction (b) of $\mathrm{Cu}$-phthalocyanine film vacuum-evaporated on a cleavage face of mica kept at $150^{\circ} \mathrm{C}$. 
向するととが観察され，基板温度と蒸着速度の配向に及 ぼす影響から，実効過飽和度が配向を支配するとみられ ている。

銅フタロシアニンのような平面分子は, 分子面を 0.4 $\mathrm{nm}$ 前後の間隔で平行に積み重㸚パッキングしたカラム を形成し, 結晶はこのカラム軸方向に成長する。白雲母 上の銅フタロシアニン蒸着膜は基板の加熱条件により,

Fig. 3 のような 3 方向，または 1 方向に伸びた板状晶 より形成される13)。これはフタロシアニン結晶がカラム 軸を基板に平行にとり, 白雲母のへき開面のシリケート 層の六方対称加, 内部構造による単斜対称の相互作用に より，3万向または 1 万向に配向成長したととを示して いる。

$400^{\circ} \mathrm{C}$ で熱処理した後, $150^{\circ} \mathrm{C}$ に保った白雲母上に形 成した銅フタロシアニン蒸着膜は, Fig. 4 亿示すよう

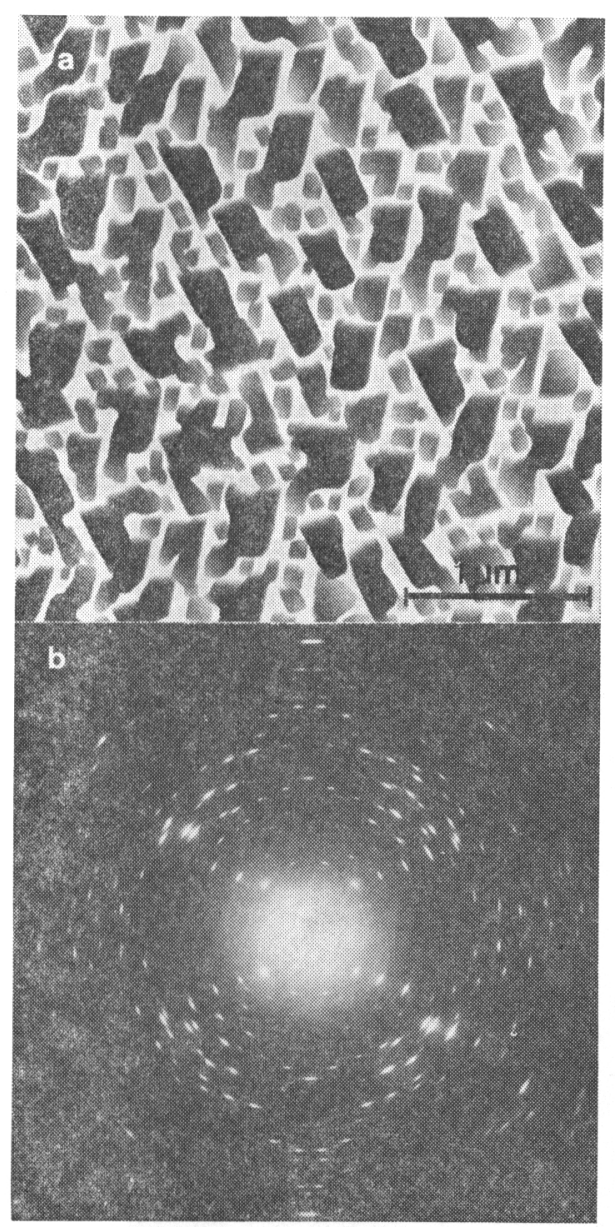

Fig. 4 Electron micrograph (a) and electron diffraction (b) of $\mathrm{Cu}$-phthalocyanine film vacuum-evaporated on a cleavage face of mica which is preheated at $400^{\circ} \mathrm{C}$ and kept at $150^{\circ} \mathrm{C}$.
に長方形のブロック状結晶から形成され, 膜の電子線回 折像は白雲母の $\mathrm{a}$ 軸と $60^{\circ}$ の方向を対称にとる 2 組の層 状の網目模様が重なっている ${ }^{14)}$ 。逆格子では結晶のカラ ム軸に刘応する逆格子基本ベクトルが他の逆格子基本ベ クトルに比べ大さいので, 回折斑点は Fig. 4(b)のよ うに, 同じ逆格子基本ベクトルをむつ逆格子面毎に層状 に分かれて現れ解析を容易にしている。塩化カリウム結 晶上でも銅フタロシアニン蒸着膜は全く同じ配向をと $り^{15)}$, 回折斑点の指数と強度分布から結晶の基板に対す る傾きが求められる。平面分子の結晶内におけるパッキ ングの形態と対比すると,フタロシアニン分子は Fig. 5 のように基板の塩化力リウムの (001) 面に平行に接し, ポルフィリン環の窒素原子が $\mathrm{K}^{+}$イオン上に配位して吸 着した平行配向をとり，との分子を核として続いて蒸着 する分子がカラム状にパッキングして結晶は成長する。

したがって, 銅フタロシアニン蒸着膜は基板結晶の種

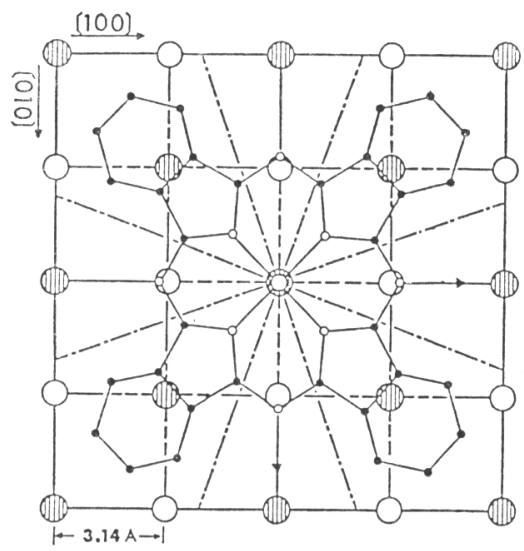

Fig. 5 The lattice structure of the cleavage face of $\mathrm{KCl}$ and the orientation relative to the deposited molecule of $\mathrm{Cu}$-phthalocyanine.

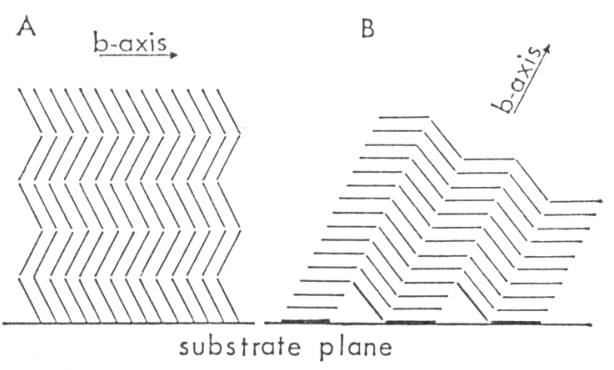

Fig. 6 Schematic diagrams of orientation of $\mathrm{Cu}$-phthalocyanine molecules in the crystal. A : the crystal with the parallel b-axis orientation.

$\mathrm{B}$ : the crystal with the standing b-axis orientation. 
類, 蒸着条件により Fig. 6 のように, カラムが基板に 平行に成長した結晶と, 分子が基板に平行に吸着してカ ラムが斜立して成長した結晶の 2 種類の配向をとる。他 の金属フタロシアニン13,16), フラバンスロンやインダン スロンなどの縮合多環芳香族キノンの蒸着膜 ${ }^{17)}$ む, 同様 な 2 種類の配向をとることが電子線回折によりみいださ れている。

\section{2 デコレーション法}

岩塩へき開面に真空蒸着した $\mathrm{Au}$ は, 蒸着初期には表 面のステップや欠陷に沿って核を形成し微粒子が一列に 並ぶので, 炭素蒸着膜で補強してから岩塩を水で溶解し てレプリカ膜とし，Au 微粒子の分散状態から岩塩の表 面構造を観察するととがでさる。このような表面レプリ カ法をデコレーション法という。有機分子は電子線損傷 を受け易く，薄膜を直接電子顕微鏡で観察するのは困難 なととがある。岡田ら ${ }^{18)}$ は直鎖分子のステアリン酸の単 結晶上に $\mathrm{Ge}$ を真空蒸着し，炭素蒸着膜で補強した後ス テアリン酸を溶解してレプリカ法で観察した結果,

Fig.7のように結晶面によって蒸着した $\mathrm{Ge}$ 粒子の形態 が異なっているととをみいだした。結晶の基底面 (001) では蒸着 Ge 粒子は星形形状で不連続な島構造をとり， 側面(110) では Ge は微粒子の連続膜となる。ステアリ ン酸単結晶の (001) 面は分子末端の $\mathrm{CH}_{3}$ 基, (110) 面 は分子側面の $\mathrm{CH}_{2}$ 鎖からなり, $\mathrm{Ge}$ は $\mathrm{CH}_{3}$ 基との相互 作用が他の金属と異なり星形に成長するもの之思われ る。ステアリン酸及びステアリン酸カルシウムの蒸着膜 中の分子配向が, 蒸着 $\mathrm{Ge}$ 粒子の形状から決定されてい
$3^{11,12)}$ 。

ポリエチレンを真空中で加熱すると, 基板上に分子量

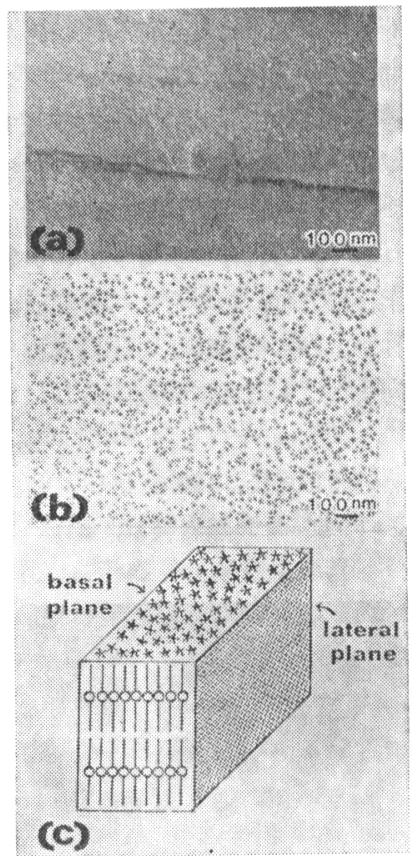

Fig. 718) Morphology of $\mathrm{Ge}$ particles vacuumevaporated on a single crystal of stearic acid. (a): continuous film on stearic acid (110) plane, (b) : island structure on stearic acid (001) plane, (c) : schematic diagram of basal (001) and lateral (110) planes of stearic acid.

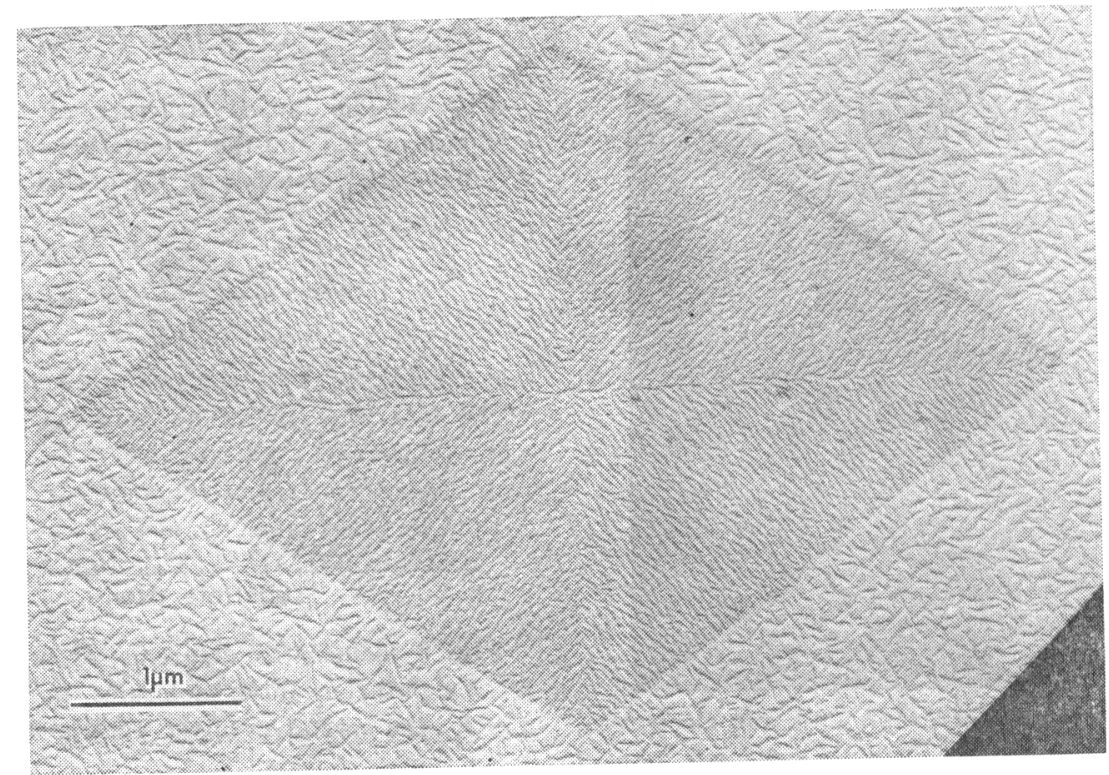

Fig. $8^{19)}$ Decorated single crystal of a polyethylene fraction $\left(M_{w}=20,000\right.$, $M_{w} / M_{n} \approx 1.1$ grown from a dilute solution. 
約 3000 に低分子化したポリエチレンの蒸着膜を形成す $ろ^{8)}$ 。Wittmann ら ${ }^{19)}$ は溶液加ら成長させたヘキサトリ アコンタンとポリエチレンの四辺が $\{110\}$ 面からなる 菱形単結晶上に，ポリエチレンを真空蒸着して膜の形態 を観察した。単結晶の（001）面上に微細な一定方向に成 長した棒状晶が密に分布して膜を形成する。パラフィン 単結晶上では棒状晶の長軸は下地結晶の $\{110\}$ 成長面 に垂直な 2 方向に配向して成長し，交差した編目模様を 形成している。一方，ポリエチレン単結晶上では Fig. 8 のように，菱形結晶を 4 分割した三角形の中で蒸着ポリ エチレンの棒状晶はそれぞれの（110）面に垂直に配向 して成長している。同じ形の単結晶を形成する両分子 とあ直鎖状分子であるが，その長さは全く異なり，パラ フィン単結晶の表面は末端 $\mathrm{CH}_{3}$ 基の露出面であり, ポ リエチレンでは長い鎖の折りたたまれた面である。パ ラフィン結晶の表面エネルギの最低位置は〈110〉と 〔010〕方向に平行にあり，配向成長する結晶の下地との 相互作用は低指数の高充てん面の接触が有利であるの で，蒸着ポリエチレン分子は〈110〉方向に平行に吸着 され，(110）面を下地結晶と接して成長する。ポリエチ レン単結晶の (001) 面は分子鎖の折りたたまれた面で あり，配向した鎖七グメントの折りたたみやループのた めに溝が形成されている。蒸着ポリエチレン分子は溝に 沿って付着し，続いて凝縮する分子はその周りに平行に 並んで配向した核となり，(310）面を下地結晶にほぼ平 行にとった棒状結晶として成長すると説明している。ポ リオキシメチレンの六角板状単結晶上の蒸着ポリエチレ ン膜は，六角形を 6 等分した各三角形の中で棒状結晶が 成長面である㲽垂直に配向して，分子が同じ方向に折
りたたまれている領域之，結晶成長の中心を明らかに示 している。このように高分子単結晶上の蒸着ポリエチレ ン膜は, 単結晶表面の分子鎖の折りたたみ方向を示すこ とから, Wittmann らはポリマーデコレーション法と名 付けている。

\section{3 高分解能電子顕微鏡法}

電子顕微鏡による結像は本質的には光学顕微鏡の場合 と変わらず, 分解能は A bbe の式で与えられる。

$$
\delta=0.61 \lambda / \alpha
$$

$\delta$ は分解能， $\lambda$ は電子の波長， $\alpha$ は対物レンズの絞りの 開口角である。分解能を高めるには散乱する電子を大き い角度でとりいれて結像させるか, 波長を短くするため 加速電圧を高くすれば良い。しかし，レンズの収差を無 くすることは不可能なので, Scherzer らは期待できる 分解能を次式で表した。

$$
\delta=0.63 C_{s}^{1 / 4} \lambda^{3 / 4}
$$

Cs はレンズの球面収差係数である。達成されている分 解能は加速電圧 $200 \mathrm{kV}$ で $0.2 \mathrm{~nm}, 500 \mathrm{kV}$ で $0.14 \mathrm{~nm}$ などがある。

塩素化銅フタロシアニン分子は電子線照射に強い有機 物で, 塩化力リウム結晶上に蒸着すると, 平面分子は基 板結晶上に平行吸着し，分子面は基板にほぼ垂直に積み 重なっている。したがって，膜面に垂直に電子線を入射 すると，カラム中の分子が一枚の分子像に重なり合って 各原子のコントラストが強まり, 直接分子像を得ること

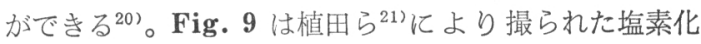
銅フタロシアニンの分子像である。四つ葉のクローバー 型の分子形之周縁部の 16 個の塩素原子がはっきりと観 察できる。高分解能像のコントラストは撮影条件の僅か

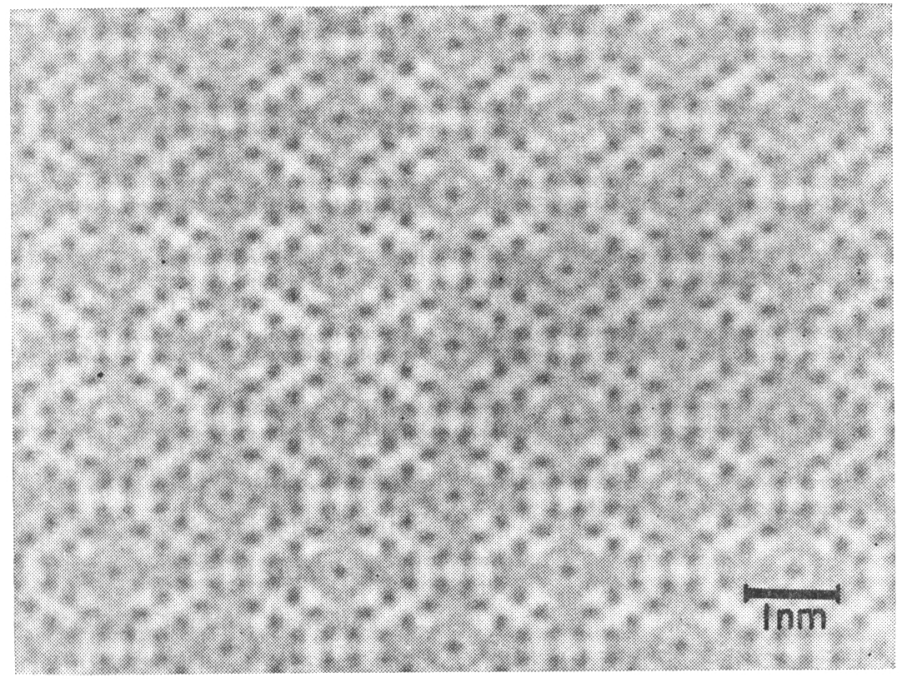

Fig. 9 ${ }^{21)}$ Molecular image of chlorinated Cu-phthalocyanine. 


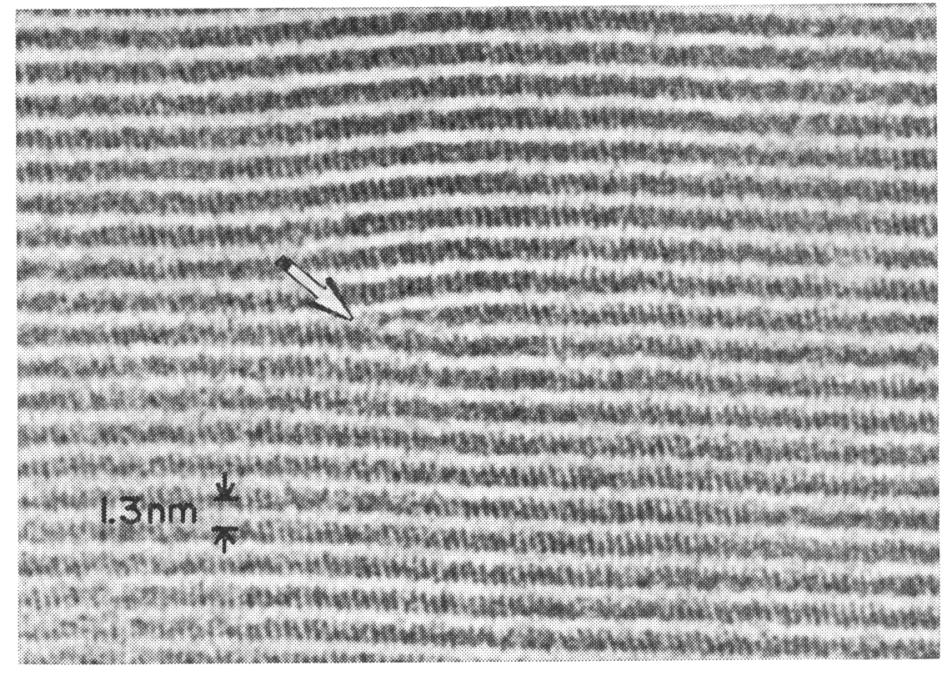

Fig. 10 ${ }^{22)}$ Molecular image of $\mathrm{Pt}$-phthalocyanine viewed along a perpendicular direction to the molecular column. An edge dislocation indicated by the arrow is formed by insertion of a column.

な違いで大きく変動するので, 像の解釈は結晶構造の計 算機によるシミュレーション像と比較検討して行わねば ならない。Fig. 9 の分子像はシミュレーション像の強度 分布とよく一致して扔り, 分子像を直接観察した最初の 例である。Fig. 10 は白金フタロシアニンの分子カラム が基板に平行に配向している結晶の高分解能像である。 基板面に立っている平面分子が力ラム軸に対して斜めに 平行に重なってパッキングしていることがよく分かる。 また，矢印で示したようにカラムの插入による刃状転位 の存在も明らかである ${ }^{22)}$ 。

このように高分解能法は格子像, 分子像などの直接観 察により分子配列，構造不整などを手早く解明するとと ができる。分子像の観察には分子が照射損傷を受け難い こと，分子像を結像しうるように分子が適当な配向を とっていることなどの制約があり，現在では適用は一部 の分子に限られている。しかし, 有機超薄膜の物性は有 機分子の配向に上る異方性に依存しており, 薄膜中の分 子レベルの構造や欠陥を明らかにするためには, 高分解 能法による評価が一層重要となろう。電子線による分子 の損傷を防ぐためには，電子線量を最小限に制御する最 小照射装置を用いたり，極低温に試料を泠却することが 試みられている。この方法により気一固相反応の未知生 成物の同定之構造の決定も行われている ${ }^{2325)}$ 。

\section{3. $L B$ 膜}

LB 法は親水基と疎水基をあつ分子を水面上に展開 し，压縮により水面に親水基を揃えて並んだ単分子膜を
形成させ，これを基板上に移しとり単分子膜，または累 積膜を作成する有機分子独特の製膜法で，脂肪酸やその 金属塩など多くの化合物に適用されている。単分子膜で は電子密度が低くて電子顕微鏡像のコントラストが弱い ので，検鏡試料は LB 膜を支持膜上に移しとり, Ptや $\mathrm{Au}$ の金属を真空中で斜め蒸着する, いわゆるシャドウ ウイング法により膜表面のステップや欠陷を観察した り，基板上に移した膜を炭素などの真空蒸着膜で覆い， LB 膜を溶解して表面のレプリカ像を観察するレプリカ 法が用いられている。LB 膜は基板上に移しとった単分 子膜, または累積膜として利用されるので, 使用する基 板上の膜構造について十分知らねばならない。

Ries ら ${ }^{26)}$ はコロジオン膜上に移しとったへキサトリ アコンタン酸の LB 膜をシャドウイング法により初め て観察し，低い表面圧では膜は島状構造をとり，高い表 面圧では多数の穴を屯つ一様な膜となり，崩壊直前の表 面圧で連続した一様な膜が得られると述べている。その 後ホルムバール膜上に移したコレステロールの LB 膜 にあ島状構造を観察している ${ }^{27)}$ 。Neuman ${ }^{28)}$ はコロジオ ン膜上の単分子膜は表面圧に依存し，低表面圧と中間的 表面圧ではコロジオン膜上には部分的にしか単分子膜は 移行せず，LB膜は島状構造であると述べている。 $\operatorname{Spink}^{29)}$ は雲母, ガラス及びコロジオン膜上ではステア リン酸の LB 膜は完全に移行して均一な膜が得られる が，膜には $0.1 \mathrm{~mm}$ に達する穴が多数あいていると述心 ている。このように研究者により異なっている観察結果 を踏まえて, Fereshtehkou ら ${ }^{30)}$ は表面圧と基板のステ 
アリン酸の単分子膜の構造に及ぼす影響について調べ, ホルムバールやコロジオン膜のような低エネルギ表面へ は，低または中間の表面圧では単分子層の一部しか移ら ないが，十分に高い表面圧では定量的に移行する。ステ アリン酸のような単分子膜は，付着した表面でかなり不 安定で構造的な再配列が生ずる。マイカやガラスのよう な高エネルギ表面では連続した一様な膜が得られると述 べている。LB 膜の構造は表面圧, 移しとる基板の表面 エネルギと表面の粗さに影響を受けるから，LB 膜を用 いる研究ではまず膜の構造を確認してかからねばならな W。

\section{4. むすび}

配向性有機薄膜である真空蒸着膜と LB 膜について, 電子顕微鏡による配向の評価方法と, これまでに得られ た薄膜の配向を評価した。すでに述べたように，有機分 子は電子線損傷を受け易く，熱に弱く，また真空中では 昇華し易いなどの性質をもつものが多く，電子顕微鏡に よる観察には多くの制約がある。さらに検鏡試料は支持 膜上に載せねばならず，LB 膜でみたように，使用する 基板上での膜構造がそのまま保たれているかどうかとい う問題もある。有機薄膜では薄いほど分子の配向による 異方性が顕著になるので, 配向の完全な制御が要求さ れ，またその評価が重要となる。薄膜の電子顕微鏡によ る観察は微小部分の楧造を評価し得る方法であり, 超薄 膜中では分子レベルでの配向の乱れや欠陥についての情 報を与えてくれる。したがって，今後はてれらの制約を 克服する技術が進歩し，問題点も十分考虑したうえで， 有機薄膜の構造の評価に電子顕微鏡による薄膜の直接観 察が益々盛儿になるであろう。

\section{文献}

1) 竹中 亭: 応用物理 55.903 (1986).

2) S. Hashimoto, K. Seki, N. Sato and H. Inokuchi : J. Chem. Phys. 76, 163 (1982).

3) J.C. Buchholz and G. A. Somorjai : J. Chem. Phys. 66, 573 (1977).

4) 原田義也, 増田茂, 尾崎弘行: 応用物理 55. 863 (1986).

5) Y. Ueda and M. Ashida : J. Electron Microsc. 29, 38 (1980).

6) M. Ashida and Y. Ueda: "Preprints IVth Int. Confer. on Vapour Growth and Epitaxy" (Nagoya, 1978) p. 286.

7) Y. Ueda : Bull. Chem. Soc. Jpn. 59, 3375 (1986).
8）服部幸和，芦田道夫，渡辺禎三：日化誌 1975 , 496 (1975).

9) M. Ashida, Y. Ueda and T. Watanabe: J. Polym. Sci., Polym. Phys. Ed. 16, 179 (1978).

10) M. Ashida, Y. Ueda and H. Yanagi : Bull. Chem. Soc. Jpn. 59, 1437 (1986).

11) F. Matsuzaki, K. Inaoka, M. Okada and K. Sato: J. Cryst. Growth 69, 231 (1985).

12) T. Miki, K. Inaoka, K. Sato and M. Okada : Jpn. J. Appl. Phys. 24, 672 (1985).

13) N. Uyeda, M. Ashida and E. Suito: J. Appl. Phys. 36, 1453 (1965).

14) M. Ashida: Bull. Chem. Soc. Jpn. 39, 2625 (1966).

15) M. Ashida : Bull. Chem. Soc. Jpn. 39, 2632 (1966).

16) M. Ashida, N. Uyeda and E. Suito: Bull. Chem. Soc. Jpn. 39, 2616 (1966).

17) M. Ashida, A. Hamada and T. Watanabe: Bull. Chem. Soc. Jpn. 45, 2312 (1972).

18) 稲岡紀子生, 佐藤清隆, 岡田正和: 電子顕微鏡 13, 138 (1978).

19) J.C. Wittmann and B. Lotz: J. Polym. Sci., Polym. Phys. Ed. 23, 205 (1985).

20) N. Uyeda, T. Kobayashi, E. Suito, Y. Hamada and N. Watanabe: J. Appl. Phys. 43, 5181 (1972).

21) N. Uyeda, T. Kobayashi, K. Ishizuka and Y. Fujiyoshi : Chemica Scripta: 14, 47 (1978-79).

22) T. Kobayashi, Y. Fujiyoshi and N. Uyeda : Acta Cryst. A 38, 356 (1982).

23) N. Uyeda, T. Kobayashi, K. Ishizuka, Y. Fujiyoshi, H. Inokuchi and G. Saito: Mol. Cryst. \& Liq. Cryst. 125, 103 (1985).

24) Y. Ueda, M. Ashida, Y. Fujiyoshi, N. Uyeda and J.R. Fryer: Proc. XIth Int. Cong. on Electron Microscopy, Kyoto vol. 2, p. 1405 (1986).

25) H. Yanagi, Y. Ueda and M. Ashida: Proc. $\mathrm{XI}$ th Int. Cong. on Electron Microscopy, Kyoto vol. 2, p. 1747 (1986).

26) H.E. Ries Jr. and W. A. Kimball: Nature (London) 181, 901 (1958).

27) H. E. Ries Jr., M. Matsumoto, N. Uyeda and E. Suito: J. Colloid Interface Sci. 57, 396 (1976).

28) R. D. Neuman : J. Colloid Interface Sci. 50, 602 (1976).

29) J. A. Spink: J. Colloid Interface Sci. 23, 9 (1967).

30) S. Fereshtehkou, R. D. Neuman and R. Ovalle : J. Colloid Interface Sci. 109, 385 (1986). 